DOI: $10.15503 /$ jecs20142.112.125

\title{
THE EXPERIENCE OF THE HITLER YOUTH - BOYS IN NATIONAL-SOCIALISM
}

\author{
DOMINIK FIGIEL \\ Faculty of Pedagogy, University of Wroclaw, \\ ul. J. W. Dawida 1, Wroclaw, Poland \\ E-mail address: dfigiel.uwr@gmail.com
}

\begin{abstract}
Losing the First World War, unemployment, the generation gap and the cult of youth led to the party of Adolf Hitler gaining popularity in the Weimar Republic. Using slogans of the restoration of a strong Germany the national socialists organized structures, which formed and educated German Youth.

Hitler Youth - brought up according to the rule: "youth leads youth" - was a very fertile environment for the spread of the idea of national-socialism. The specific values - racial supremacy, honour, obedience handed down by parents were the beginning of the Nazi indoctrination.

In the later period such organizations as Bund Deutscher Madel or Hitlerjugend took power over German youth. Education, upbringing, ideological content used by the institutions in Nazi Germany are described in the extensive literature on the subject. However, very important are the experiences of individual members of the Hitler Youth that show the Nazi youth activities from a time perspective. Experiences such as the wisdom of life, and gained knowledge, enable recognition and description of the reality which is discussed.

The scope of historical and pedagogical research shows the essential facts constituting the full picture of the life of young people during Nazi era.
\end{abstract}

Keywords: experience, Hitler Youth, upbringing, Hitlerjugend, national-socialism, ideology, remembrance, education, boys.

'The twentieth century is rightly proud of its civilization: scientific, technical and educational development, and in this sense it was the century of the child1. On the other hand, it has become a century of unprecedented barbarism: devastating wars, ruthless genocide, blind local fights and ethnic cleansing, and cults of any kind of xenophobia and discrimination. These phenomena naturally impinge on the children's fate and upbringing. Children are the victims, but they are also intentionally involved into the most shameful acts. And this is what the educational crises and disasters of the century depend on (Wołoszyn, 2008, p.180).

1 Ellen Key "Centruty of the Child” edited in 1900. 
The pedagogical thought of this period presents a picture of a variety of directions and positions, aspirations, goals and ideals. Educational reality is reflected in it equally with any other difficulties, the struggle for the true meaning of life with the political and social propaganda (Chmaj, 1962, p.9.). The complexity of the situation of the child in the twentieth century decided me to make it the area of my analysis. This choice is connected with Guido Knop's statement that Hitler youth was a generation of young people who had been deprived of choice (Knopp, 2008). In the Third Reich enslaved citizens raised their children to be enslaved people in order to feel that in some area they had power (Heck, p. 93). In all varieties of fascism there is no respect for the rights and life of a child, spiritual death is spread and its ideology castrates souls (Miller, 1999, p. 82). 'The ideology of Adolf Hitler is an example of a distorted outlook, which was the result of life experience and was a mixture of extreme racist attitude, primitive Darwinism and properly prepared mythology (Gutek, 2007, p. 256).

As an object of my reflection I made the individual fate of a man involved in the social reality of the National Socialist period. I decided to limit my consideration to the situation of boys in the Third Reich, as the consideration of the role, tasks, and place of girls requires a separate analysis.

The purpose of this topic is to look at the fate of individuals from the perspective of experience and their analysis in the historical and pedagogical context and the transfer of individuals experience according to magistra vitae est history ${ }^{2}$. It is essential to present the conclusions based on the analysis of the individual experience of Hitler Youth and areas important for examining educational contexts.

I paid particular attention to youth relationships with their families and organizations such as the Hitlerjugend. It is significant, because 'history is the description of the mutual relations between people and between them and their surroundings. As a result, what is the truth about history, is generally true of political thought and of human action as well' (Berlin, 2002, p.55).

The analysis of the individuals experience, called the wisdom of life allows the incorporation into reflection on historical and pedagogical content relating to the position and situation of young people living in countries with totalitarian regimes.

In the subject literature the attention is drawn to the anthropological function of education, which can only be a research challenge, when a human is noticed both from the perspective of his experienced world (subjective living environment and life experience), but also from the perspective of the course of his life (biography). This category of biography, in the historical sense allows us to give education its temporal and spatial character, defining a framework of the shaping process in the individual dimension (Lalak, 2010, p.51). Moreover, among many autobiographical materials, honorable place is occupied and an important source of knowledge 'individual or collective experience saved in the memory of the participants and witnesses of certain social and political events(Theiss, 1996, p.28)'.

Biography has specific dimensions. In its real dimension it refers to the course of life (external perspective), and the area of individual experience, such as knowledge, achievements, experiences (internal perspective). They influence each other in creating a unique, individual picture of life experience with a processual character which is cognitively available to the awareness of the subject (Lalak, 2010, p.110).

2 History is a teacher of life 
When we take into account a number of factors: relationships, community, family, youth organizations, ideology, national socialist movement etc., we can make biographical and autobiographical analysis, how the individual experiences of the boys involved in the social reality of National Socialism was developed and created. The argument in favor of a detailed look at this issue are Alfons Heck's words: 'the history of the Nazi youth can be repeated(Heck, n.d.).' And 'experience of boys in National Socialism, which I decided to analyze 'are a huge example of children's abuse (Heck, n.d.).'

\section{HITLER YOUTH - BOYS}

The formation of the Nazi youth ${ }^{3}$ organization is described in details in the subject literature, as well as the process of indoctrination ${ }^{4}$ and education ${ }^{5}$ in Nazi schools. These materials are the solid base for a comprehensive analysis of the subject individual experience. However, it should be explained how they wanted to see the individual in the Nazi regime and what the process of education looked like.

Devotion of the individual and reducing it to the molecule, the atom entails according to Hitler - the renunciation by the individual of the right to express their opinion; defend their own interests and their own happiness. This renunciation is the essence of political organization in which the individual renounces expressing their personal opinion and their interests. Hitler praised selflessness and taught that in the pursuit of their own happiness people even easier fall from heaven to hell. The purpose of education is to teach an individual compromising his ' $I$ '. Since at school boy must learn not only to be silent when rightly rebuked, but also bear in silence injustice if necessary(Fromm, 1970, p.113).' Education and student's development should aim to convince him that he absolutely dominates the others(Fromm, 1970, p.109). In the next part, Hitler stated that 'my rules are hard. Weakness must be crushed. In the fortified bastions of my order, there will grow young people who will terrify the world. I want strong, imperious, undaunted, cruel youth. This is the youth I want. They must bear the pain. They mustn't have anything weak and fragile. They must have free, commanding, wild beast in their eyes. I want strong and beautiful youth. In this way I will be able to create a new world(Miller, 1999, p.157).'

This presented ideal of the Nazi child's education suits the military needs of the German society. E. Fromm stated 'in fact, we should not owe certain types of social character to educational techniques, but they are one of the mechanisms by which these characters are formed. In this sense, knowledge and understanding of educational methods is an important part of a comprehensive analysis of the society functioning(Miller, 1999, p.157).'

3 Dearn A., The Hitler Youth 1933-45, Great Britain 2006; Hammer J., Hitler's Children, „Newsweek” 2000, nr 135; Kater M.H., Hitler Youth, London 2004; Knopp G., Dzieci Hitlera, Warszawa 2008; Kunzer E.J , Education under Hitler, "Journal of Educational Sociolgy"1939, nr 3; Kunzer E.J., The youth of Nazi Geramny, "Journal of Educational Sociology 1938, nr 6; Lampen C., Hitler Children: Education as Indoctrination under the Third Reich, Maine 2012; Lewis B.R., HitlerJugend. W czasach wojny I pokoju 1933-1945, Warszawa 2008; Pine L., Education in Nazi Germany, England 2011; L. Pine, Nazi Family Policy 1933-1945, England 1999.

4 E.C. Król, Propaganda and indoctrination of National Socialism in Germany in 1919-1945, Kraków 2000.

5 K. Grunberg, Hitlerjugend, Torun 1998; E. Krieck, Nationalpolitischer Erziehung, Leipzig 1928, E. Krieck, Philosophie der Erziehung, Jena 1928, E. Krieck, Erziehing im nationalpolitische Staat, Berlin 1931, Pine L., Education in Nazi Germany, England 2011. 
Understanding the social function of education depends on implementation of the individual to perform the role, which is to be played later in the society; it means the molding of the character to be similar to a social character and create the desires of the individual to be consistent with the requirements of its social role. This function determines the educational system of any society; that is why we cannot explain the structure of society or the personality of its members by the educational process, but on the contrary, we must explain the educational system by the needs arising from its social and economic structure (Fromm, 1970, p. 138).

Individual life stories allow effective cognition of given educational methods. They give the answer for the question, in what extent and circumstances, ideas of Adolf Hitler were internalized. Furthermore, 'writing and autobiography is to be an evidence to an extraordinary experiences, suffering, or it may be a kind of examination of conscience - sins confession and actions absolution, difficult, sometimes extremely, put an autobiography author in the state of serenity(Demetrio, 2000,p. 121).'

\section{SEARCH AREA}

There is a question 'how to study and describe an enslaved childhood, the relationship that occurred between the children and the young and the enemy and aggressive totalitarian country?(Theiss, 1996, p. 19)'. First of all, you should analyze the fate of individuals from the perspective of a biography being formed under the influence of certain historical realities. Then we can distinguish such factors as: the general historical conditions, the elements of the social structure and specific situational factors, that is, both the individual characteristics of the individuals, as well as the unique life situations. The study subject includes both, the influence of factors which determine the fate of the individual and their self-preserving behavior. In this aspect we should take into account: actions determining the survival of the individual, as well as values and ideals stimulating the life quality(Theiss, 1996, p. 19).

According to $\mathrm{W}$. Theiss at the intersection of the two dimensions there is a so-called field of enslavement, it is, life situations that arose in specific socio-political realities, and they particularly restricted the development of the young generation. In addition, he notes that separate spheres should be observed: the sphere of danger, devastation or values(Theiss, 1996, p. 19). As a result, the effect of existence and the totalitarian country of nomenclature(Theiss, 1996, p. 18) activities lead to the human and the national enslavement ${ }^{6}$.

Francis Blachnicki describes an enslaved man, as 'the man who is the ultimate result of all the efforts and activities of the system. The man who, in all his existential and humanistic needs feels endangered and lives in constant fear, who cannot be himself, who is always forced to duplicity, to pretend, who has to approve what he feels disgust for, agree when he should disagree. A man treated like a productive animal, like a labor slave without a sense of purpose and creative joy, constantly, forcibly fed, what for him is indigestible - dumb propaganda and lies (Blachnicki, 1985,p.152).'

6 According with F. Blachnickiego, it is strictly agreed and specified class of people who, after meeting the relevant requirements and going through a complicated system of verification were admitted to the exercise of power and the use of its privileges. 
According to Andrzej Grzegorczyk 'danger of coercion and enslavement appears everywhere, where in social life there is violence understood as a challenge to operate the overwhelming power (Grzegorczyk, 1979, p.63)'. In order to explore different sites and forms of enslaved childhood, whose chance is to enrich the knowledge of the socialization and education of young generations with new, unknown or little known dimensions, it is important to save from oblivion the unique experiences of children and young people living in the extreme socio-political situations (Theiss, 1996, p.1215). Enslavement depends on imposing certain behavior by means of violence against the will of individuals, groups, the environment or society (Theiss, 1996, p.15). It starts with humiliation, where everything else is secondary (Tischner, 1990, p. 175). Enslavement is achieved by violence, it means will dependence of the weaker on the stronger(Grzegorczyk, 1979, p.68). The result of it is a world of enslaved children, where childhood is broken because of direct or indirect influence of extreme socio-political situations: war, ideological violence and rapid, constitutional transformation(Theiss, 1996, p.12). Against this background, W. Theiss determines the role of the study on enslaved childhood. In documentary terms it is a reproduction of socio-political and cultural history of the child and childhood. At first glance it is a tedious and unattractive procedure. However, it does not preclude the discovery of completely unknown or almost unknown events and circumstances in which the history of childhood is rich. The theoretical perspective relates to the questions included in the particular social diagnosis. These are the questions about the origin of certain phenomena, and their development phase, as well as their relevance to the life of children and youth. The methodology in this area should serve to improve existing research instruments, especially classic research methods, such as biographical methods. In the category of knowledge, it is important to show the enslaved childhood as a broader picture of the world of cruelty and tragedy, directly or indirectly set against children and young people and leading to general conclusions about the nature of the lesson for the modern world. The third role - moral - is connected with the cognitive dimension, with the enrichment of knowledge about man, his behavior in the world in extremely difficult conditions(Theiss, 1996, p.29-31). Thus, the subject of the search are unitary experiences of children - boys. The search area extends from education in the family to the closest environment and youth organizations.

\section{REFLECTIONS ON "EXPERIENCE" OF THE SUBJECT}

As Danuta Lalak states 'it is difficult to imagine a more competent source of knowledge about the world than the balance of human experience, expressed in a subjective way(Lalak, 2010, p. 133).' Wilhelm Dilthey adds that 'from the life reflection, experience is created. Particular events, that are caused by the cluster of drives and feelings, meeting with the surrounding world and fate, are formulated in the general and subject knowledge. Just as human nature is always the same, the essential features of life experience are common to all people.'(Dilthey, 1987,p.121). However, it should be emphasized, that the basis of our experience are the processes of exchanges of information with the external environment'(Krzyżewski, 2003, p. 259). Whereas, 'in consideration of the ontogenetic development of the individual experience of the 
individual is often considered as a factor of development. Speaking of experience, we point at situations in which an individual gains specific knowledge or acquires certain forms of behavior as a result of contact with the external environment and events in the internal life. How the experience, that an individual gets, affects its moral development, and what kind of experience seems to be particularly conducive to this development(Krzyżewski, 2003, p.199).' Human life is considered in terms of psychophysical unity, in which the important role is played by the concept of human consciousness. It gives the individual shape of the human experience and development, it lets us speculate on the thesis of biographical uniqueness. According to J. Dewey awareness is closed in experience (Lalak, 2010, p. 16). 'It is a stream, and it shapes the nature of human experience, which is fully determined by the subject activity (Lalak, 2010, p. 34).' Therefore, experience depends on the subject activity , his will, and any object of experience can be of neutral value (Lalak, 2010, p. 35).

It is commonly known that man, knowing what is good, often chooses evil (Dewey, 1963, p. 375). The 'knowledge of good itself is the result of a long educational process (Dewey, 1963, p. 200).' Experience strongly implies its own life activity, which is a continuous experimentation. This experimentation is the foundation of development. Experience is a continual process, emerging from the relationship between a man and the environment. This relationship is dynamic and evolutionary (Lalak, 2010, p. 36). $\mathrm{K}$. Krzyżewski points out that the environment plays an important role in the development of the individual. The result of the experience of getting the punishment in cases of breaking the rules is the strong fear connected with it, that will always accompany the individual in a situation of breaking social rules or moral norms, even when there is nobody around who would control the individual. Individual morality is the result of learning socially approved roles, related norms, where in the roots are certain moral values. The development is a gradual entering the world of values, principles and moral norms that are the creature of a particular culture and increase of compliance with these culturally relative rules and principles (Krzyżewski, 2003, p.201-202).' In his conception of experience, J. Dewey wrote that it is a way of gaining knowledge about the world and ourselves. Thanks to this, human development is carried out. In turn, the development is a social process, because it is possible thanks to the exchange of ideas between people and sharing their own experience. The real human's world is the environment - the world of his experience, the world he is aware of, not a world in general (Lalak, 2010, p. 37). Moreover, Dewey believes that in the development of the individual, the main place is taken by the educational process, which is understood as a reconstruction (reorganization) of experience. In his opinion, the ability to develop results from two sources - help from others and from own flexibility. Help from others is done through education that: is inherent in the development process, you cannot have other aims than human development(Dewey, 1963, p. 76).'In this case we are dealing with a kind of human contact with the culture, because in the course of the taking of power by the Nazis, the Nazi culture began to be created. In this context, the history of every individual life is primarily a process of adaptation to patterns and rules passed by the tradition of the community he lives in(Benedict, 1966, p 64-65). Aron Gurwitsch states that 'the world which we meet in everyday life, given to us in a simple experience, perceptions, expectations, is independent of the scientific interpretation and original. In every moment of our life we find ourselves in a world of ordinary, everyday experience (Gurwitsch, 1989, p.151).' In the context of the analysis and presentation of individual memories, it is worth noting the im- 
portance and significance of experience in life. First of all, experience is the process in which a subject acquires something which he can keep or can share with others. They are acquired involuntarily, being thrown into situations, or actively, while performing different actions undertaken intentionally. They consist of: knowledge, and skills for better, faster, more effective dealing with similar problems and situations in the future (Buksiński, 2007, p. 7). Using this, historians of education can realize in the field of historical and pedagogical research their practical and theoretical goal. It is significant that the experience becomes a source of skills, knowledge and life wisdom. The experienced provides his experience. He is a testimony by his skills, knowledge, wisdom(Buksiński, 2007, p. 7). It is important, for subject undertaken, that 'being experienced means' being able to act as a witness. Experience is the basis of the testimonies, and one testimony can be opposed to another(Buksiński, 2007, p. 7). Thus, the gained experience and reflection on it during the creation of witness narration allows an accurate picture of the individual's life. It is worth noting, following Aristotelian thought, that empeiria ${ }^{7}$ is formed from observations, imaginations, shape reminders, specific comparisons of things and their synthesis. These steps lead to concrete terms, individual judgments, or tips. And only such integrities compose the experience(Buksiński, 2007, p. 67). The materialization of attitudes 'towards' and judgments 'about' show the problems arising from the situation. Individuals, formulating specific narrations, evaluate them and show moments relevant to the researcher. Stories make individual events to be over individual and the whole series of individual and over individual, to be meaningful(Buksiński, 2007, p. 92). The experience of former members of the Nazi youth organizations are challenging research material. However, it is necessary to present the narration for a fuller and more accurate understanding of the behavior of individuals of the period of the Third Reich. It is necessary to realize that the nature of research concerning the enslaved individuals is of great importance. This is due to the fact that the youth was seen as strong and as material that will easily succumb to ideological education. Narrations of enslaved people participating in the life of the national-socialists are gaining unprecedented importance when transmitted. However this transmission must take place during human liberation. It is 'a historical consciousness of finiteness of every state of a man and society, awareness of the relativity of all kinds of faith, is the final step in the liberation of man. There a man is sovereign, and it allows him to extract from each experience, its content, devote it fully, as if there was any system of philosophy or belief that could bind him. Life becomes free from the knowledge by the terms; spirit becomes a sovereign to spider webs of all dogmatic thinking. A relativity opposes the creative power as a basic historical fact. We experience the unity of life and history, in which each part has its own meaning(Krasnodębski, 1986, p. 89).'

It is also crucial to include the category of understanding ${ }^{8}$ to the memories consideration. As the last step of triad - an experience- life expression-understanding - it removes the limit of individual experience and, on the other hand, it gives the character of life experience (Dilthey, 2004, p. 104).

Greek empeiria in ancient times included an area of life experience.

8 The category of "understanding" in the context of the concept of W.Diltheya - described in detail in W. Dilthey, Budowa świata historycznego w naukach humanistycznych, Gdańsk 2004. 


\section{MEMORIES}

It appears that all the memories transmitted as a result of the interviews, or the autobiography enrich the knowledge of the Nazi youth organizations. For purposes of this article I used interviews with former members of youth organizations (videos), autobiographies, and articles. Valuable sources are recordings - interviews with former members of the Hitlerjugend produced in a four-part series dedicated to the Children of Hitler. The presented material was divided into categories that show the image of the enslaved child. They relate to the attitude towards youth organizations, life in them, the family and fulfilling the duties towards the country. It is worth noting that these sources contain a reflection of their being in the past. People who presented their memories, gave their own experiences, reveal the brutal truth about the functioning of the totalitarian system. The choice of the unique issue, which is the experience of the individual was not accidental. It was connected with the quote of Alfonso Heck, an autobiography author, a former member of the Hitlerjugend, who said that he could not vouch for the accuracy of provided names and dates, but he is sure of what he has experienced in the days of Nazi Germany(Heck, 1985, p. 13). The same author also stated that he is responsible for committing mass murder just like Baldur von Schirach because he fanatically served Hitler (Heck, n.d.)'. Admitting to the committed crimes indicates a very high consciousness of the individuals towards to the entire indoctrination, propaganda and educational activity. In discussing particular memories and the resulting experience, it is worth starting from the attitude of individuals towards the organization. About the belonging to Hitlerjugend, many former members speak very positively. A. Heck says, 'except the fact that I was so far away from home alone for the first time, there immediately appeared a feeling of belonging to the best and important movement(Heck, n.d.).: Other interlocutors said that for them it was a pride (membership in organizations - D.F), because they meant something, in addition they felt someone who they had not been before. Important people with important tasks(Hitler's Children-seduce, n.d.). They said that they were wearing the same clothes and singing the same songs in the group they felt as if they were at home, more than if they really were at their family home (Hitler's Children-boys, n.d.). Carl-Albert Schluter mentions that 'we felt proud, and really, it was absolutely great in those uniforms'(Knopp, 2008, p. 42). 'Even though they came from different environments, the uniform made them equal. Metalheads and workers' sons were equal to the teacher's sons. Uniforms gave us equality. They were companions (Hitler's Children-seduce, n.d.). It is mentioned that an important meaning was attributed to the sense of community. Lothar Schultz says that 'during the ceremony, while singing songs full of dignity, we felt bound with community. At that moment, we could die for the fatherland(Knopp, 2008, p. 33)'. Egon Thun adds, 'beginning from Ortsgruppernleiter to Fuhrer Pimpfow, we all were members of one big community (Hitler's Children-seduce, n.d.)'. In the evenings - as one of the members reports - we were sitting by the bonfire and singing. It was dark, and the stars were shining in the sky, it was a moving experience, that you do not forget(Hitler's Children-seduce, n.d.)'. So other members wrote that 'they told us that we are the best, that we are their hope for the future (Hitler's Children-boys, n.d.)'.

There appeared also feelings associated with the fact that members of Hitlerjugend decided about what was happening in the society. In addition, what A. Heck wrote - 
'my days in the Hitler Youth were my happiest days, generally speaking: I was young and I was becoming a fanatic(A child of Hitler, n.d.). Memories authors' reflection in relation to the actions of the German leaders was connected with the rebellion and intergenerational dialogue. One of the interviewees stated that 'the rebellion was absorbed by Hitlerjugend and was used by the Reich for their own purposes. We rebelled against the rest of the world(Hitler's Children-seduce, n.d.)'. Members themselves thought that 'old people do not understand anything, are decrepit. Those things get to the young people (Hitler's Children-seduce, n.d.)'. Sybil Schonfeldt mentions that 'the National Socialists cleverly used this feeling that probably accompanies each child at adolescence, when it seems to be a better than its parents and wants to walk their own ways in rebellion against them (Knopp, 2008, p. 54)'. In addition, - Hans Muller says - 'It was said: you are ... the youth is ... And the old have no clue anyway. They do not know what is going on - they are calcified. Something like that, of course, gets to the young people. Especially when one considers that education was not a liberal then as it is today, but to a much greater extent it was based on obedience(Knopp, 2008, p. 58)'.

An important role, as former members of Nazi organizations think, was the ability to 'tempt' the young - 'if you want something from somebody, you have to skillfully tempt. And they did it skillfully (Hitler's Children-boys, n.d.)'. First of all, 'children had nothing to do during holidays, they were sitting on the balcony or the streets. Only some were going on holidays to their grandmothers in the country. And suddenly they could go off for 2 or 3 weeks. So they were going. Actually, they were never going(Hitler's Children-seduce, n.d.)'. In addition, 'there were many attractions, we traveled, we took part in maneuvers, we skied, we walked the in the mountains, we swam in the lakes. What more could the boys want (Hitler's Children-boys, n.d.)'. The organization of the Hitlerjugend indoctrination process works perfectly. However, it should be noted what role parents played, knowing that they send their children to places, where they would go through an effective indoctrination. At the beginning, 'of course - according to one of the members - I was proud, pleased with being at school and that my parents were proud of me. I was happy that I passed so difficult an exam (Hitler's Children-boys, n.d.). That is why Erich Loeche adds, 'parents of all the classmates were for the Nazis. Nobody gave me reason to think anything bad about the Nazis. Often, what people said was in $100 \%$. Everything was in 100\%. I also supported the Nazis 100\% (Hitler's Children-seduce, n.d.) '. Even when Martin Borman Jr. asked his father 'Dad, tell me what is National Socialism?' It was three years after the Main Kampf release. This question really surprised my father, but I will remember it forever. National Socialism is the will of the Fuehrer (full stop). The word 'full stop' was a part of his answer (Hitler's Children-boys, n.d.). Of course, there also appeared stories that made the young people not want to have anything in common with their parents. As the interviewee says: 'when I was with Hitlerjugend, there was an incident that embarrassed me. Today talking about it, I feel embarrassed, but at the same time I am glad that I can take a load off my mind. My father did not want to have anything in common with NS, at that time I was sleeping with my brother in a small room near the kitchen. One night I heard some voices. One of them was the voice of a Jew. The Jew wanted to cross the border. My father ordered me to stay, and he would guide that man. And he guided the Jew, he returned alone. I must honestly admit that then I did not want to be a son of my parents (Hitler's Children-seduce, n.d.)'. Klus Bouel also mentions a moment of joining the organization, and the reaction of his parents - 'my mother and father immediately wanted me to join Jungvolk, they did not want me to be different and at the age of 10 or 
11 stay outside the group(Hitler's Children-seduce, n.d.)'. 'It was depicted that anyone who was outside the organization did not belong to the German nation. He was like a leper. He did not belong the society of great Germany(Hitler's Children-seduce, n.d.)'. Very significant are the words of the author of reportage about the Hitler youth, who says that 'parents resigned from the right to raise children when they joined the Hitlerjugend. They were not able to take the competition(Hitler's Children-seduce, n.d.)'. The evidence is also memories relationship between former members and the words of youth organization leaders : 'only sissies go for a walk with their mothers. They liked to use this term. A sissy. But nobody, including me, wanted to be a sissy. So the bond with their parents had to be broken(Hitler's Children-seduce, n.d.)'.

The attitude of youth towards the organization, as well as towards the family was a deliberate action of the entire national socialist party which demonstrated an experience connected with the conscious rebellion against older (parents), and with the situation in which they found themselves. They were the circumstances the Nazis used, on the one hand the weakness of individuals: boredom, the lack of prospects, on the other hand, the force they had. This potential was seen in the young age of individuals, in their commitment, and willingness to exercise power. Nazi leaders let young people exercise power within the structures of the Hitlerjugend. The opportunity to rule the others gave them much satisfaction, as one of the former members mentions ' a 12-year-old boy could rule the ten-year old. Attention - get down, and you had to lie down in the mud. In this way they started to crave higher functions. They became Jugendschaft Fuhrers ${ }^{9}$ with 10 subordinates, and later Fähnlein fuhrers ${ }^{10}$, and then you commanded a hundred of people, it was very tempting for the young, and they knew it. It worked with many, including me (Hitler's Children-seduce, n.d.)'. Karl-Heinz Jass adds that 'when I gave an order I knew it would be obeyed. When I asked them to sing, they sing. When I told them to march, they marched. It was clear that in the Hitlerjugend it was like in the army (Hitler's Children-seduce, n.d.)'. As Johaness Koppen states 'it is always a nice feeling, to stand in front of a division and give orders. Then you have a feeling that you have achieved something. Although you do not know what you have achieved, but this power is uplifting (Hitler's Children-seduce, n.d.)'. In turn, Paul Stuben thought that ' those who controlled the streets, controlled people (Hitler's Children-seduce, n.d.).' The enigmatic image of Hitlerjugend made it so that this organization became an attractive area of activity for young people. The sense of community, of perpetration, aim unity, gave the impression of fulfillment. The post-war experience of individuals shows a completely different reality. The proposal of Nazi leaders turned out to be utopia. In turn, it was closely connected with the enslavement of individuals. This situation is clearly shown by Shlomo Perel: 'We were nothing, our life was worth nothing, we had to devote our life for a banner. This type of appeal directed to young people sentenced them to death. Can there be a bigger crime against young people? And it was an appeal directed to the 12-13 year old children (Hitler's Children-seduce, n.d.).' In addition, attention should be paid to Hralad Grundmann's statement, who relates to the practical tips. He claims that 'the biggest victims of betrayal and all this fraud were those who did not survive, it is more than half of us. Those who live today should admit to their carelessness and do their best in order to protect their

\footnotetext{
The smallest organizational unit of a population of 10 boys.
}

10 The unit consisted of about 150 boys. 
children and grandchildren from similar fate(Hitler's Children-boys, n.d.).' There are also other statements showing specific considerations related to children's suffering. We can use the words of H. Grundmann who states that 'the greatest harm that they managed to do was taking away from us of compassion. Sharing someone's opinion is one thing. A sympathy or empathy is something completely different. It was necessary to avoid them, they managed to inculcate in us (Hitler's Children-boys, n.d.)' , and $\mathrm{H}$. Grundmann 'I'm ashamed of how little we knew about German writers and poets, for example about Man. Our knowledge of mathematics was also pathetic. In comparison with my grandchildren, we were just ignorant (Hitler's Children-boys, n.d.).'

The presented statements reveal the reality which the young German generation of national-socialism period had to face. The experience they provide in their narrations show contents that should be included in the study on the consequences of ideological education. It is worth having a closer look, in the context of shaping the experiences of individuals, at observations associated with the attitude towards themselves, ideology and contents, which were passed in the upbringing and education process. The words of one of the former members of the Hitlerjugend are very significant 'at a time when we were to take power, the Jewish issue was to have been solved a long time ago. There should not have been any Jews and Germany was supposed to be already clean. We did not think about Auschwitz and the gas chambers. Things like that did not come to our minds. We could not believe that something like that was really happening. Expel them - yes - but to kill - no. Superhumans just do not not act this way, it is beneath his dignity. We were extreme idealists (Hitler's Children-boys, n.d.)' . Interlocutors 'were firmly convinced that the Jews were the embodiment of evil (Hitler's Children-boys, n.d.)'. A. Heck, considered the deportation of Jews to be necessary. He concludes that it was caused by the continuous Nazi indoctrination, changing the reference to faith (Heck, n.d.). In addition you heard about the camps for stubborn people, refusing obedience to A. Hitler, even though he wanted the best for them. Asking about chimneys, they told them (members of the Hitlerjugend - D.F.) that this was a crematorium. And before the next questions were asked, you could hear the answer. There work more people than live in Weimar , about 50 thousand. In Weimar there is a crematorium and it is here. This answer was enough. They believed it. It was said that they were Germany's enemies and they had to be isolated from the rest, so that they could not disturb during the fight(Hitler's Children-boys, n.d.). Very interesting is also the confession of A. Heck, who then, as a 10 year old boy (Knopp, 2008, p.150), witnessed Kristallnacth the brutality committed on people who he did not know. For him, it meant the end of the German innocence. He says that from that moment, no one could argue they did not know what was happening to the Jews(Heck, n.d.). The hostile attitude towards the Jewish nationality was emphasized at every step of the members of Hitlerjugend performance. P. Stuben tells the story, which shows the situation of the child making the choice: ' while marching we reached a savings bank. Outside there was placed a poster Der Sturmer. Finelinefuhrer saw the cabinet and shouted: death to the Jews. The shouting began at the front in the first division. It began to grow like a wave, until it reached the back where I was, but I was not able to shout with the others, I moved only my mouth. Finally, something broke inside me. I thought: death to the Jews ?. They talk about the country of Judea, somewhere far away in the south. If I join in this shouting, it will not harm anyone. I shouted with others and it was very bad (Hitler's Children-seduce, n.d.).' Living in a period of National Socialism, you could not make a different decision. It was necessary to act as the community ordered. This resulted from the fact that it 
was believed that the Germans were a race of lords, to rule the world (Heck, n.d.). Uwe Lemprecht states that 'the rule was simple: you are nothing, your country is the most important. Germany must survive even if we die. It must exist even when we're gone (Hitler's Children-boys, n.d.).' Ernst-Christian Gatka emphasizes that 'everything they did with us, had one aim, I understood it after many years. This aim was to prepare us for a heroic death(Hitler's Children-boys, n.d.).'. Besides - as Hans-Gunther Zempelin claims- 'we were to be faithful Fuhrer's squires and convinced national socialists. We had to think for ourselves, to manifest our own will, to be able to break through and make independent decisions. It was a paradox. You cannot be a convinced national socialist faithful to Fuhrer and at the same time a man thinking critically(Knopp, 2008, p.168).'The education process of Hitlerjugend members can be summarized by the words of Hans-Georg Bartholomai: 'our education was tough, authoritarian, completely undemocratic and nowadays completely inconceivable(Knopp, 2008, p.150)'. Presented memories reflect the reality in which the generation of the Hitler youth lived. On their basis the experience of individuals is revealed and it introduces new content to the practice and theory of education. The question is, what are the experiences that enrich knowledge of the educational ideology of the Third Reich, and whether they can be put into categories describing the actions towards the youth? For practical purposes, what direction should historical and pedagogical research pursue, which makes the analysis of educational ideology.

\section{CONCLUSION}

When we consider that experience is a way of gaining knowledge about the world and ourselves, and that thanks to it the development of human is possible, then we can agree with D. Lalak's view about experience as the most competent source of knowledge about the world of the individual. In all statements there appear separate judgments, acting tips, as well as reflections on themselves. It is crucial that, the experience of the individual is considered from two perspectives. The first concerns the individuals sharing their memories as witnesses, who found themselves in the reality allowing them to gain concrete experience. Secondly it concerns, the time and circumstances in which these memories are converted into experience and passed on. This expression allows you to specify the categories that will be contributed to the historical and pedagogical research. First of all we need to isolate from presented memories, the experience connected with the found world ${ }^{11}$, it is the period before and after the taking power by the national socialists. The example is mentioned by the interviewees: the situation of young people after the Germans lost World War I, boredom, lack of prospects, the monotony of everyday life. The second category is the imposed world, which is a consequence of the found world. At this level, the individuals experienced actions (indoctrination) by the national socialists. In their memoirs, it has been named the skilful tempting. It was reflected in the sense of urgency, power, and community. At that time, they organized camps, trips, training, holidays and they assured a variety of activities with which most young people had not had contact. They also realized primary aims

11 Separation of the Worlds allows you to specify the situation in which there were German society under the rule of the National Socialists. Allows recognition of experience in the categories of building up experience. 
in the form of imposing the way of thinking and acting. They introduced the ideal of education corresponding to the aspirations of the Nazis to create a race of lords. An important function in the educational process which was totally subordinated to the Nazi ideology. In the imposed world children treated Hitlerjugend like an adventure and fun. At the third level - an enslaved world - the members of Hitlerjugend were aware of the real aspirations of the National Socialists. Individuals experience is connected with the situation of boys prepared to perform military functions. There was the systematic breaking of family ties. Devoting life to the country had become the watchword, and individualism was replaced with communalism. Individuals began to realize the content transmitted in the educational process. The extermination of the Jews was to be implemented, and the Hitlerjugend members had to participate. The culmination of enslavement at the stage of the enslaved world was to be the heroic death of the members of Hitlerjugend in the fight for the defense of Germany . The last category is a liberated world. An individual shares his experience, gives his knowledge and provides his advice. He also analyzes his life from the perspective of time and reality in which he is located. He compares his life with the life of individuals free of the totalitarian regime. He allows researchers to understand and know the situation in which there were children and youth. It is reflected in the understanding of the goals and aspirations of the national socialists. For the theory and practice of historical and pedagogical extract the four worlds allow us to analyze the consequences of intentional Nazis actions. Each world becomes an integral part of building and gaining experience. The last category includes an important element of constructing the narration. The fundamental aim of presenting the worlds ${ }^{12}$ is the awareness of existing in each ideology, the categories describing educational actions with respect to children. In addition, the historical educational research must be focused on ideology, as an element that belongs to the found, imposed, enslaved or liberated world. It depends on the environment in which the individual exists or situation in which there is in a given country. It is also crucial that a man shapes his experience, and which level, described in the world he is located depends on the memories analysis.

12 Found world, imposed world, enslaved world, liberated world 
Journal of Education Culture and Society No. 2_2014

\section{REFERENCES}

A child of Hitlers. Growing up in the Third Reich. (2008). Retrieved from http://thephoenix.com/Boston/ News/55446-A-child-of-Hitler/?page=1\#TOPCONTENT

Benedict, R.(1966). Patterns of culture. Warsaw: Wydawnictwo MUZA S.A..

Berlin, I.(2002). Sense of reality. Poznan: Zysk I S-ka.

Blachnicki, F.(1985). The truth - the cross - liberation. To Polish liberation theology. Warsaw: Maximilianum. Buksiński, T.(2001). Experience in the social sciences. In: T. Buksiński (Ed.), Experience, (pp 67). Poznan: UAM.

Chmaj, L. (1962). Currents and trends in pedagogy of XX century. Warsaw: Państwowe Zakłady Wydawnictw Szkolnych.

Demetrio, D.(2000). Autobiography. The therapeutic dimension of writing about yourself. Krakow: IMPULS. Dewey, J.(1963). Democracy and upbringing. Warsaw: Ksiązka i Wiedza.

Dilthey, W.(1987).The essence of philosophy. Warsaw: Państwowe Wydawnictwo Naukowe

Dilthey, W.(2004). Construction of the historical world in the humane science. Gdansk: Słowo/obraz terytoria. Fromm, E.(1970).Escape from freedom. Warsaw: Czytelnik.

Grzegorczyk, A.(1979). Philosophy of time trial. Warsaw" Pax.

Gurwitsch (1989), Problems of experienced world. In: Z. Krasnodębski (Ed.), Phenomenology and sociology. A collection of Texas (pp.151). Warsaw : PWN.

Gutek, G. (2007). Philosophy for educators. Gdansk: Gdańskie Wydawnictwo Pedagogiczne.

Heck, A.(1985). A child of hitler. Germany in the days when the God wore swastika. Phoenix: Renaissance House. Heil Hitler! : Confessions Of A Hitler Youth. (1991). Retrieved from http://www.tcm.com/tcmdb/title/467815/ Heil-Hitler-Confessions-of-a-Hitler-Youth/

Hitler's children - Boys. Retrieved from http:/ / topdocumentaryfilms.com/hitlers-children/

Hitler's children - seduction. Retrieved from http://www.ovguide.com/hitler's-children-9202a8c04000641 f80000000057c9673

Knopp, G. (2008). Hitler's children. Warsaw: Świat Książki.

Krasnodębski, Z.(1986). Understanding human behavior. Warsaw: Państwowy Instytut Wydawniczy.

Król, C.E.(2000). Propaganda and indoctrination of National Socialism in Germany in 1919-1945. Warsaw: Rytm. Krzyżewski, K.(Ed.).(2003). The experiences of the individual. Krakow: Wydawnictwo Uniwersytetu Jagiellońskiego.

Lalak, D. (2010). Life as a biography. Warsaw: Wydawnictwo Akademickie "Żak".

Miller, A. (1999). Prisoners of childhood. Poznan: Media Rodzina.

Theiss, W.(1996). Enslaved childhood. Warsaw: Wydawnictwo Akademickie "Żak".

Tischner, J.(1990). Philosophy of drama. Warsaw: Znak.

Wołoszyn S. (2008). Education and upbringing in XX century. In: Z. Kwiecieński, B. Sliwerski (Ed.), Pedagogy, Vol. 1 (pp. 180). Warsaw: PWN 